\title{
Assessing Refugee Claims In Canada
}

\author{
Mennonite Central Committee Canada (MCCC)
}

A Submission to the Parliamentary Committee Studying Bill C-55 on Refugee Determination, September 2, 1987

In twenty-four of the 50 countries where we are active in development and relief projects we are also assisting refugees. In Thailand and since 1981, MCC has operated the Canadian cultural orientation program for all Indochinese refugees who come from the camps in that country to Canada. In Honduras MCC provides personnel and money to assist local Mennonites in a major involvement in the two largest camps for refugees from El Salvador. In Somalia MCC workers continue to provide social assistance and agricultural services to Ethiopian refugees, a task begun in 1981. Recently, an MCC worker played a key role in arranging the voluntary repatriation of 2,800 refugees in Somalia to the province of Sidamo in southem Ethiopia.

In addition to our work abroad, we have in private sponsorship an avenue for resettling refugees in Canada. This is done under a "Master Agreement" with the government, first signed in 1979. The following figures tell part of that story.

\begin{tabular}{|cccc|}
\hline $1979 / 80$ & 1981 & 1982 & 1983 \\
3,800 & 442 & 226 & 223 \\
& & & \\
1984 & 1985 & 1986 & 1987 \\
297 & 400 & 542 & 700 \\
& & & (proj.) \\
\hline
\end{tabular}

We developed a program to "complement" the government's work, meaning that we would try to get our churches to sponsor those whose special needs might prevent them from being sponsored by the government: single parent families, families with a handicapped child and those with limited vocational or language skills. We decided on this approach and to focus on Thailand, Somalia and on Central Americans in the U.S.

Work With Central Americans in the United States

Assistance to Central Americans in the U.S. has been emphasized in the last five years. The "Overground Railroad", in which Mennonite Central Committee U.S. is a major partner, has assisted approximately 1,000 Central Americans in coming to Canada via Canadian Consulates in the U.S. Most of these entered through the government sponsorship stream.

The MCCC offers to sponsor applicants if private sponsorship is needed. But the Consulates place most applicants in the government sponsorship stream. We therefore have provided sponsorship for only 27 Central Americans from the U.S. in 1986. Given this framework, projected totals for 1987 are 120 , a figure which reflects the increased demand as well as media attention.

Why not apply for refugee status in the U.S.? Mainly, chances of gaining asylum are very slim if applicants came from a country that is a U.S. ally. Salvadoran applicants' acceptance rates, for example, have in the past four years been less than $3 \%$ while the rate for Guatemalans is less than $1 \%$. Application for asylum in the U.S. gives only temporary legal status until the case is denied: then applicants are subject to deportation. Refugees are reluctant to apply for asylum because there is no guarantee that confidentiality will be respected. They fear exposing relatives and co-workers in Central America.

The new U.S. Immigration law has made it illegal for employers to hire undocumented aliens. Without work authorization and no access to welfare, many 'underground' people are left with a poor choice: starving, going back to Latin America where in many cases their lives will be in danger, or seeking status in Canada which, under current legislation could also endanger them. The refugees' trust in the 'Overground Railroad' route, and our involvement with them in that route is vital to this presentation.

The 'Overground Railroad', while preferring to assist refugees to get into Canada through the Consulates, finds that this is not a realistic option for some cases. The following cases typify basic reasons why Central American refugees in the U.S. need the outlet of a border presentation.
Refugees Have No Legal Way o Supporting Themselves in the U.S.

Case study 1. We found D-, a Guatemala widow with 5 children and several othe relatives living in a barren apartment. The fam ily fled Guatemala after her husband was she while driving the family into their lot. It woul, take six months to process an applicatio through the Chicago Consulate. In Canad they hope that the older sons can begin earnin immediately in order to support the family.

Refugees in Detention who have come $t$ the end of the U.S. asylum applicatio! process are about to be deported.

Case study 2 . We found R - in the El Centr Detention Centre in California, about to $b$ deported. R- had fled El Salvador two year ago because of death threats. A $\$ 5,000$ bon. would release this person from the Detentio Centre. A Minnesota farmer and friend provided that bond. They arranged for an inter view at the Canadian border and they are no: making resettlement plans with friends in Can ada.

Refugees Whom the Canadian Consul Refuse or are Unable to Hear, but wh we feel have a strong and urgent case

Case study 3. We found L-, a Guatemala who had been pursued by the judicial police $i$ Guatemala. This person was told by a Canadi an Consulate in the northern U.S. that applice tion must be made in a Guatemalan city sinc that was the "residence" place. Of course Lcould not go back because that was also "th danger to life" place.

Case study 4. M-, a Seventh Day Adventi: who refused to serve in the military because $c$ religious pacifist convictions, was denied asy lum in 1986 by the Canadian Consulate $i$ Dallas. M- was subsequently deported to $\mathrm{E}$ Salvador. After interrogations, slanderou accusations and threats to family. $M-w i$ denied a hearing on the evidence. The Const late said that this person had "had the chance." In Los Angeles the Canadian Const late's quota is full. Applicants are told to appl next year.

Those Whose Lives are Endangered i the United States

mCase study 5. M- belonged to ANDES, th El Salvador teachers' union. With many other

Cont'd on page 1

4 